\title{
Spinel to Rock-Salt Transformation in High Entropy Oxides with Li Incorporation
}

\author{
Junbo Wang ${ }^{1,+}\left(\mathbb{D}\right.$, David Stenzel ${ }^{1,+} \oplus$, Raheleh Azmi ${ }^{2}{ }^{\oplus}$, Saleem Najib ${ }^{3}$, Kai Wang ${ }^{4}$, \\ Jaehoon Jeong ${ }^{1} \mathbb{D}$, Abhishek Sarkar ${ }^{1,5} \mathbb{D}$, Qingsong Wang ${ }^{1} \mathbb{D}$, Parvathy Anitha Sukkurji ${ }^{1} \mathbb{D}_{\text {, }}$ \\ Thomas Bergfeldt ${ }^{6}$, Miriam Botros ${ }^{1}\left(\mathbb{D}\right.$, Julia Maibach ${ }^{2} \mathbb{D}$, Horst Hahn 1,5,7 (D), \\ Torsten Brezesinski ${ }^{1, *(D)}$ and Ben Breitung ${ }^{1, *(D)}$ \\ 1 Institute of Nanotechnology, Karlsruhe Institute of Technology (KIT), 76344 Eggenstein-Leopoldshafen, \\ Germany; junbo.wang@kit.edu (J.W.); david.stenzel@kit.edu (D.S.); Jaehoon.jeong@kit.edu (J.J.); \\ abhishek.sarkar@kit.edu (A.S.); qingsong.wang@kit.edu (Q.W.); parvathy.anitha@partner.kit.edu (P.A.S.); \\ miriam.botros@kit.edu (M.B.); horst.hahn@kit.edu (H.H.) \\ 2 Institute for Applied Materials-Energy Storage Systems, Karlsruhe Institute of Technology (KIT), \\ 76344 Eggenstein-Leopoldshafen, Germany; raheleh.azmi@kit.edu (R.A.); julia.maibach@kit.edu (J.M.) \\ 3 Faculty of Engineering, University of Waterloo, Waterloo, ON N2L 3G1, Canada; \\ muhammad.najib@partner.kit.edu \\ 4 Department of Materials and Earth Sciences, Technische Universität Darmstadt, 64287 Darmstadt, Germany; \\ kai.wang@partner.kit.edu \\ 5 Joint Research Laboratory Nanomaterials, Technische Universität Darmstadt and Karlsruhe Institute of \\ Technology (KIT), 64206 Darmstadt, Germany \\ 6 Institute for Applied Materials-Applied Materials Physics, Karlsruhe Institute of Technology (KIT), \\ 76344 Eggenstein-Leopoldshafen, Germany; thomas.bergfeldt@kit.edu \\ 7 Helmholtz Institute Ulm for Electrochemical Energy Storage, 89081 Ulm, Germany \\ * Correspondence: torsten.brezesinski@kit.edu (T.B.); ben.breitung@kit.edu (B.B.) \\ + Authors contributed equally.
}

Received: 21 February 2020; Accepted: 11 March 2020; Published: 16 March 2020

\begin{abstract}
High entropy oxides (HEOs) constitute a promising class of materials with possibly new and largely unexplored properties. The virtually infinite variety of compositions (multi-element approach) for a single-phase structure allows the tailoring of their physical properties and enables unprecedented materials design. Nevertheless, this level of versatility renders their characterization as well as the study of specific processes or reaction mechanisms challenging. In the present work, we report the structural and electrochemical behavior of different multi-cationic HEOs. Phase transformation from spinel to rock-salt was observed upon incorporation of monovalent $\mathrm{Li}^{+}$ions, accompanied by partial oxidation of certain elements in the lattice. This transition was studied by X-ray diffraction, inductively coupled plasma-optical emission spectroscopy, X-ray photoelectron spectroscopy, transmission electron microscopy, and attenuated total reflection infrared spectroscopy. In addition, the redox behavior was probed using cyclic voltammetry. Especially, the lithiated rock-salt structure HEOs were found to exhibit potential for usage as negative and positive electrode materials in rechargeable lithium-ion batteries.
\end{abstract}

Keywords: high entropy materials; high entropy oxides; phase transformation; electrochemical energy storage; Li-ion batteries

\section{Introduction}

The concept of entropy stabilization in multi-component alloys has gained increasing interest in recent years, starting with the synthesis of high entropy alloys (HEAs) [1,2]. Since the first report 
on HEAs, controversial discussions about the role of configurational entropy have continued to take place, while a solid proof of entropy stabilization is still lacking [3]. High entropy materials typically comprise a variety of different elements and are characterized by forming single-phase lattice structures, despite the potential propensity of the incorporated elements to crystallize into different phases when separated $[4,5]$. Recently, this concept has been applied to ceramics, resulting in the development of high entropy oxides (HEOs) [6,7], carbides [8,9], borides [10], nitrides [11], and many other materials [12-14].

The first paper on HEOs was published by Rost et al. in 2015 and reported about the rock-salt structure of equimolar ( $\mathrm{NiCuZnMgCo}) \mathrm{O}$ (space group $F m-3 m$ ) [7]. Since then, a large number of studies on different structures and application of HEOs have been reported [15-17]. For example, Dabrowa et al. elaborated on the homogeneity of spinel-type $(\mathrm{NiFeMnCrCo})_{3} \mathrm{O}_{4}$ (space group $F d-3 m$ ) [16]. In addition, the recent findings by Bérardan et al. on ( $\mathrm{NiCuZnMgCo})_{1-x-y} \mathrm{Ga}_{y} \mathrm{~A}_{x} \mathrm{O}$ (with $\mathrm{A}=\mathrm{Li}, \mathrm{Na}$, $\mathrm{K}$ ) showed that the charge compensation mechanism when using monovalent elements involves the formation of oxygen vacancies, resulting in a decrease in lattice parameters [18]. Lately, HEOs have been shown to have potential as conversion, intercalation, and insertion materials for application in Liand Na-ion batteries (LIBs and SIBs) [5,13,17,19-22]. Nevertheless, the role of $\mathrm{Li}^{+}$in HEO structures (e.g., rock-salt [23] or spinel [24]) and the associated behaviors of the other incorporated elements have not yet been understood.

While the lithiation mechanism of binary or ternary oxide systems has been investigated quite extensively, the lithiation of HEOs has largely remained unclear due to their complex nature (the presence of different metal ions makes a detailed analysis very complicated). However, investigations into the evolution of lattice structure in conventional transition-metal oxides during the de/lithiation process provide valuable insights into the overall mechanism and help in postulating theories to explain the observed crystallographic changes [5]. A good example is the transition of $\mathrm{Co}_{3} \mathrm{O}_{4}$ from a spinel phase into a rock-salt phase upon lithiation, either by chemical or electrochemical means. The spinel material converts into a partially ordered rock-salt compound $\left(\mathrm{LiCo}_{3} \mathrm{O}_{4}\right)$ with $\mathrm{Li}$ insertion into octahedral $16 \mathrm{c}$ Wyckoff sites, leading to a shift of $\mathrm{Co}^{3+}$ positions from the tetragonal 8a sites to adjacent octahedral sites [25-28].

In this work, we study the effect of $\mathrm{Li}$ incorporation on the lattice structure of spinel-type materials $(\mathrm{NiFeMnCrCo})_{x} \mathrm{O}_{y},(\mathrm{NiFeMnCrMg})_{x} \mathrm{O}_{y}$, and $(\mathrm{NiFeMnZnMg})_{x} \mathrm{O}_{y}$. The Li content was gradually increased by tailoring the amount of precursor used in the synthesis. The addition of monovalent ions to a mixed $\mathrm{M}^{2+} / \mathrm{M}^{3+}$ (spinel) or $\mathrm{M}^{2+}$ (rock-salt, with $\mathrm{M}=$ metal) phase requires charge compensation and, depending on the Li concentration, may lead to phase transformation. To gather information about the charge compensation mechanism, elements that are known to exhibit multiple oxidation states were substituted out in a stepwise approach by elements that exhibit a single distinct oxidation state $\left(\mathrm{Co}^{2+/ 3+} \rightarrow \mathrm{Mg}^{2+}\right.$ and $\left.\mathrm{Cr}^{3+/ 6+} \rightarrow \mathrm{Zn}^{2+}\right)$. In addition, the redox behavior of $\mathrm{Li}_{x}(\mathrm{NiFeMnCrCo})_{y} \mathrm{O}_{z}$ in LIB cells has been tested to assess the overall application potential in the battery field.

\section{Materials and Methods}

\subsection{Synthesis}

Three different HEO materials were prepared, namely $\mathrm{Li}_{x}(\mathrm{NiFeMnCrCo})_{y} \mathrm{O}_{z}, \mathrm{Li}_{x}(\mathrm{NiFeMnCrMg})_{y} \mathrm{O}_{z}$, and $\mathrm{Li}_{x}(\mathrm{NiFeMnZnMg})_{y} \mathrm{O}_{z}$, with gradually increasing lithium contents $(x=0,0.2,0.4,0.6,0.8$, and 1$)$. They were produced via the nebulized spray pyrolysis method [6]. To this end, equimolar solutions of the respective metal salts were prepared from $\mathrm{Ni}\left(\mathrm{NO}_{3}\right)_{2} \cdot 6 \mathrm{H}_{2} \mathrm{O}$ (Alfa Aesar, Haverhill, MA, USA, $98 \%$ ), $\mathrm{Fe}\left(\mathrm{NO}_{3}\right)_{3} \cdot 9 \mathrm{H}_{2} \mathrm{O}$ (abcr GmbH, Karlsruhe, Germany, $\left.98 \%\right), \mathrm{Mn}\left(\mathrm{NO}_{3}\right)_{2} \cdot 3 \mathrm{H}_{2} \mathrm{O}$ (abcr GmbH, $98 \%$ ), $\mathrm{Cr}\left(\mathrm{NO}_{3}\right)_{3} \cdot 9 \mathrm{H}_{2} \mathrm{O}(\mathrm{abcr} \mathrm{GmbH}, 99 \%), \mathrm{Co}\left(\mathrm{NO}_{3}\right)_{2} \cdot 6 \mathrm{H}_{2} \mathrm{O}(\mathrm{abcr} \mathrm{GmbH}, 99 \%), \mathrm{Mg}\left(\mathrm{NO}_{3}\right)_{2} \cdot 6 \mathrm{H}_{2} \mathrm{O}$ (Sigma Aldrich, St. Louis, MO, USA, 99\%), Zn( $\left(\mathrm{NO}_{3}\right)_{2}$ (Riedel-de Haën, Seelze, Germany), and $\mathrm{LiNO}_{3}$ (Alfa Aesar, 99\%). The resultant precursor solutions were transformed into fine droplets by an ultrasonic nebulizer and further transported using flowing nitrogen through a hot-wall reactor $\left(1050^{\circ} \mathrm{C}\right)$. The particles were 
collected on filter paper maintained at $120^{\circ} \mathrm{C}$ in order to prevent water vapor condensation on the deposited powders.

\subsection{Structural and Microstructural Characterization}

The structure and phase purity of the as-prepared HEO materials were examined by powder X-ray diffraction (PXRD) using a STOE Stadi P diffractometer, equipped with a Ga-Jet X-ray source using $\mathrm{Ga}-\mathrm{K} \beta$ radiation.

The elemental composition was determined by inductively coupled plasma-optical emission spectroscopy (ICP-OES, iCAP 7600DUO from Thermo Fisher Scientific, Waltham, MA, USA). About 10 $\mathrm{mg}$ of the respective samples (weighing accuracy $\pm 0.05 \mathrm{mg}$ ) were dissolved in $6 \mathrm{~mL}$ of hydrochloric acid, $2 \mathrm{~mL}$ of nitric acid, and $4 \mathrm{~mL}$ of sulfuric acid at $513 \mathrm{~K}$ for $35 \mathrm{~min}$ in a microwave oven (Speedwave Xpert from Berghof). Analysis was accomplished using four different calibration solutions and an internal standard (Sc). Two or three major wavelengths of elements were used for calculation. The oxygen content was probed by the method of carrier gas hot extraction (CGHE) using a commercial oxygen/nitrogen analyzer TC600 (LECO). The oxygen concentration was calibrated with the certified standard KED 1025, a steel powder from ALPHA, and the calibration was verified using a commercial powder (NMC $532 \mathrm{MTI}$ ). The calibration range was close to the sample concentration. The standards and the samples were weighed with a mass in the range from 1 to $3 \mathrm{mg}$ in Sn crucibles (9-10 mm). Then, $5 \mathrm{mg}$ of graphite were added and wrapped. Combined with a Sn pellet ( 200 mg), they were placed into a Ni crucible. The package was loaded in an outgassed $(5800 \mathrm{~W})$ high-temperature graphite crucible. The measurements were conducted at $5000 \mathrm{~W}$. Evolving $\mathrm{CO}_{2}$ and $\mathrm{CO}$ were swept out by helium as inert carrier gas and measured via infrared detectors.

Transmission electron microscopy (TEM) was conducted on powder samples dispersed on a lacey carbon-coated copper grid. The samples were loaded onto an FEI double tilt holder. TEM imaging data were collected using an FEI Titan 80-300 microscope, equipped with a CEOS image spherical aberration corrector, HAADF STEM detector (Fischione model 3000), EDAX SUTW EDX detector, and a Tridiem Gatan image filter. The microscope was operated at an accelerating voltage of $300 \mathrm{kV}$.

X-ray photoelectron spectroscopy (XPS) measurements were performed on a K-Alpha+ instrument (Thermo Fisher Scientific) with a monochromatic Al-K $\alpha$ X-ray source $(1486.6 \mathrm{eV})$ and $400 \mu \mathrm{m}$ spot size. The K-Alpha+ charge compensation system was applied to prevent localized charge buildup during analysis using $8 \mathrm{eV}$ electrons and low-energy Ar ions. Data acquisition and processing were carried out using the Thermo Avantage software [29]. The spectra were fitted with one or more Voigt profiles. The binding energies are reported with respect to the $C 1$ s peak of hydrocarbons at $285.0 \mathrm{eV}$. The analyzer transmission function, Scofield sensitivity factors [30], and effective attenuation lengths (EALs) for photoelectrons were applied for quantification. EALs were calculated using the standard TPP-2M formalism [31].

Attenuated total reflection infrared (ATR-IR) spectroscopy was performed using a Nicolet iS50 ATR FT-IR from Thermo Scientific.

\subsection{Electrochemical Characterization}

Electrodes for cell testing were prepared by doctor blading (100 $\mu \mathrm{m}$ slit size) on Al foil (Gelon LIB Co., Ltd., Shandong, China) and Cu foil (MTI Corporation, Richmond, CA, USA). The slurry contained $63 \mathrm{wt} . \%$ of HEO as active material, $22 \mathrm{wt} . \%$ Super C65 carbon black additive (Timcal, Bironico, Switzerland), and $15 \mathrm{wt} . \%$ polyvinylidene difluoride binder (Solef5130, Solvay, Hannover, Germany) dissolved in N-methyl-2-pyrrolidone (Sigma Aldrich). The resultant electrodes were dried in a vacuum at $80^{\circ} \mathrm{C}$ for $12 \mathrm{~h}$, followed by punching out circular disks of $13 \mathrm{~mm}$ diameter. LIB cells were assembled in an Ar-filled glovebox. Li metal foil (Gelon LIB Co., Ltd.) was used as counter electrode, glass microfiber filter paper (GF/C, Whatman, Freiburg, Germany) as separator, and $1 \mathrm{M} \mathrm{LiPF}_{6}$ in a 3:7 weight mixture of ethylene carbonate:ethyl methyl carbonate (LP57, BASF SE, Ludwigshafen, 
Germany) as electrolyte. Cyclic voltammetry was performed using a Bio-logic potentiostat (VMP3). The voltage range was set to either $2.0-4.5 \mathrm{~V}$ or $0.1-3.0 \mathrm{~V}$ versus $\mathrm{Li}^{+} / \mathrm{Li}$. The sweep rate was $0.1 \mathrm{mV} / \mathrm{s}$.

\section{Results and Discussion}

In the present work, the spinel to rock-salt phase transformation with increasing Li concentration in HEOs was investigated. Such transition is relatively well-known for simple oxides and has been the subject of many studies. However, the lithiation mechanism found here strongly differs from that observed for binary and ternary spinel compounds.

The HEOs employed were prepared via the nebulized spray pyrolysis method, allowing the incorporation of lithium without any additional chemical or electrochemical post-treatment steps. The $\mathrm{Li}$ content was gradually increased, while keeping the ratio of the other metals constant. In particular, three different HEOs were prepared, namely $\mathrm{Li}_{x}(\mathrm{NiFeMnCrCo})_{y} \mathrm{O}_{z}(\mathrm{HEO}-1), \mathrm{Li}_{x}(\mathrm{NiFeMnCrMg})_{y} \mathrm{O}_{z}$ (HEO-2), and $\mathrm{Li}_{x}(\mathrm{NiFeMnZnMg})_{y} \mathrm{O}_{z}$ (HEO-3), with $x$ varying from 0 to 1 . Upon lithiation, different structures and oxidation states were expected to evolve, as the monovalent $\mathrm{Li}^{+}$ions in mixed-valence spinel or rock-salt systems must be compensated for in order to maintain charge neutrality.

The structural transition was investigated by means of powder X-ray diffraction (PXRD). Figure 1 shows PXRD patterns of the as-prepared materials, revealing the change from spinel to rock-salt structure with increasing Li content. The elements highlighted in the respective formulas represent those that were replaced by others during the course of this study. For HEO-1 (Figure 1a), the relative intensity of the (220), (311), (422), and (511) reflections was found to decrease, while the reflection positions remained unchanged with addition of lithium. At the same time, the intensity of the (222) and (400) reflections increased, thereby indicating changes in form or structure factor of the unit cell. However, the symmetry remained unaltered. For certain Li concentrations $(x=0.6-0.8)$, the spinel phase transformed into a rock-salt structure. Upon increasing the Li content further, only reflections corresponding to the rock-salt structure were present. Notably, there were no other (crystalline) phases or side products forming. Based on the PXRD results, we conclude that the transition to rock-salt was virtually completed for $x>0.6$.

Figure $1 \mathrm{~b}$ shows PXRD patterns obtained for HEO-2, where Co has been substituted for by $\mathrm{Mg}$. X-ray photoelectron spectroscopy (XPS, see below) showed that the non-lithiated HEO-1 contained mainly $\mathrm{Co}^{2+}$. In contrast, in the lithiated state, $\mathrm{Co}^{2+}$ was oxidized to $\mathrm{Co}^{3+}$. By replacing $\mathrm{Co}^{2+/ 3+}$ with $\mathrm{Mg}^{2+}$, the charge compensation associated with the Co redox was eliminated. Hence, some changes in phase transformation behavior can be anticipated. In fact, comparing the intensities of the (311) and (222) reflections of HEO- 1 and HEO-2 for $x=0.4$ revealed some differences among the materials. This in turn suggests larger changes in structure or form factor, most probably because of differences in the overall charge compensation mechanism. Moreover, when $\mathrm{Cr}$ was replaced by $\mathrm{Zn}$ (HEO-3, Figure 1c), complete transformation into the rock-salt structure was already evident for $x=0.4$. This finding demonstrates that the transition occurred at lower Li concentrations if the average charge of the metal ions involved was reduced $\left(\mathrm{Co}^{2+/ 3+} \rightarrow \mathrm{Mg}^{2+}\right.$ and $\left.\mathrm{Cr}^{3+/ 6+} \rightarrow \mathrm{Zn}^{2+}\right)$.

Inductively coupled plasma-optical emission spectroscopy (ICP-OES) and carrier gas hot extraction (CGHE) were used to determine the stoichiometries (chemical compositions). Figure 2 shows the corresponding data for the HEO- 1 with different Li contents. While the theoretical metal to oxygen ratio of spinel-type $\mathrm{M}_{3} \mathrm{O}_{4}$ materials is 0.75 , the relative cation concentration increases when a rock-salt phase of general formula $\mathrm{M}_{1} \mathrm{O}_{1}$ is formed. This trend was indeed observed in the data, where a maximum of 0.9 was achieved. Based on the ICP-OES results, the stoichiometries of the compounds were calculated, with the details given in Table 1. Excess oxygen for high Li contents $(x>0.8)$ can be explained by the presence of $\mathrm{Li}_{2} \mathrm{CO}_{3}$ contaminants. The formation of carbonate surface species is well-known for $\mathrm{LIB}$ cathode materials (e.g., layered $\left.\mathrm{Li}\left(\mathrm{Ni}_{1-x-y} \mathrm{Co}_{x} \mathrm{Mn}_{y}\right) \mathrm{O}_{2}, \mathrm{NCM}\right)$ [32,33]. Note that $\mathrm{Li}_{2} \mathrm{O}$ and other $\mathrm{Li}$-containing impurities underwent reactions with $\mathrm{H}_{2} \mathrm{O}$ and $\mathrm{CO}_{2}$ in the ambient atmosphere. The presence of carbonates was also confirmed by attenuated total reflection infrared spectroscopy (ATR-IR) and XPS (see below). 
a) HEO-1: Li $\mathrm{i}_{x}(\mathrm{NiFeMnC} C \mathrm{Co})_{y} \mathrm{O}_{z}$

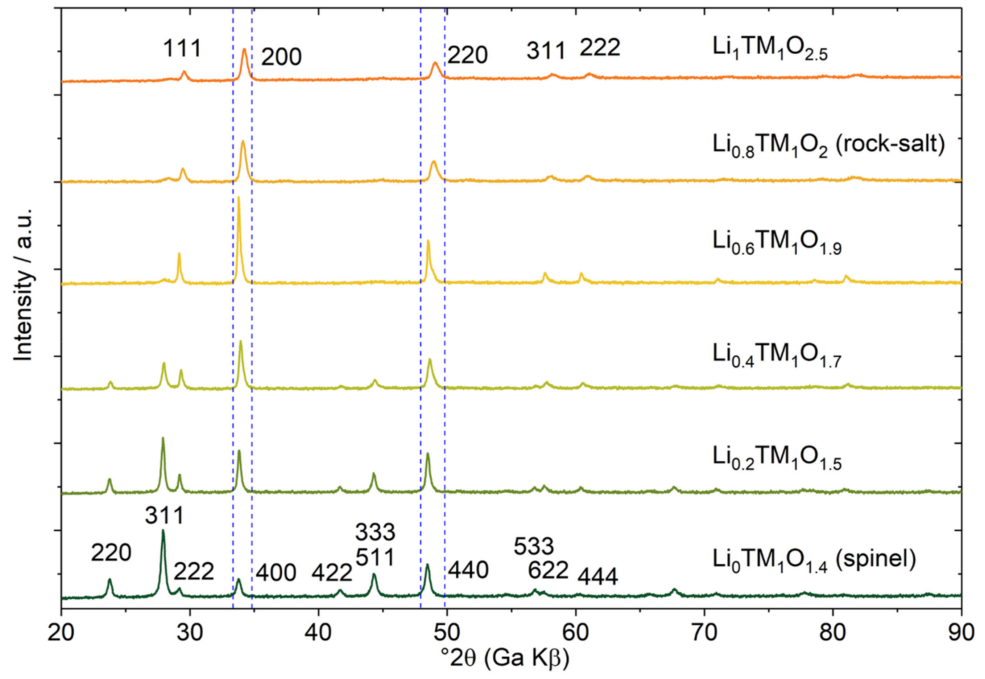

b) HEO-2: $\mathrm{Li}_{x}(\mathrm{NiFeMnCrMg})_{y} \mathrm{O}_{z}$

c) HEO-3: $\mathrm{Li}_{x}(\mathrm{NiFeMnZnMg})_{y} \mathrm{O}_{z}$
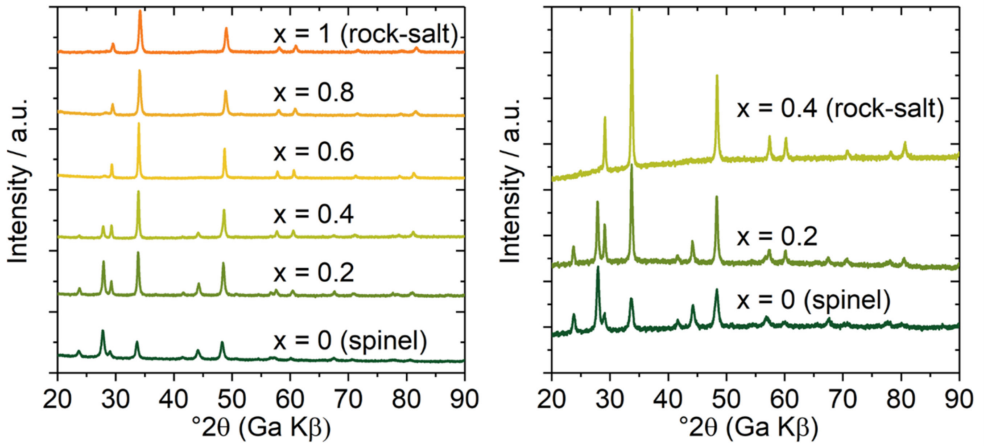

Figure 1. Powder X-ray diffraction (PXRD) patterns of (a) high entropy oxide (HEO)-1, (b) HEO-2, and (c) HEO-3 with different Li contents. Transition from spinel to rock-salt phase occurs with increasing lithium concentration.
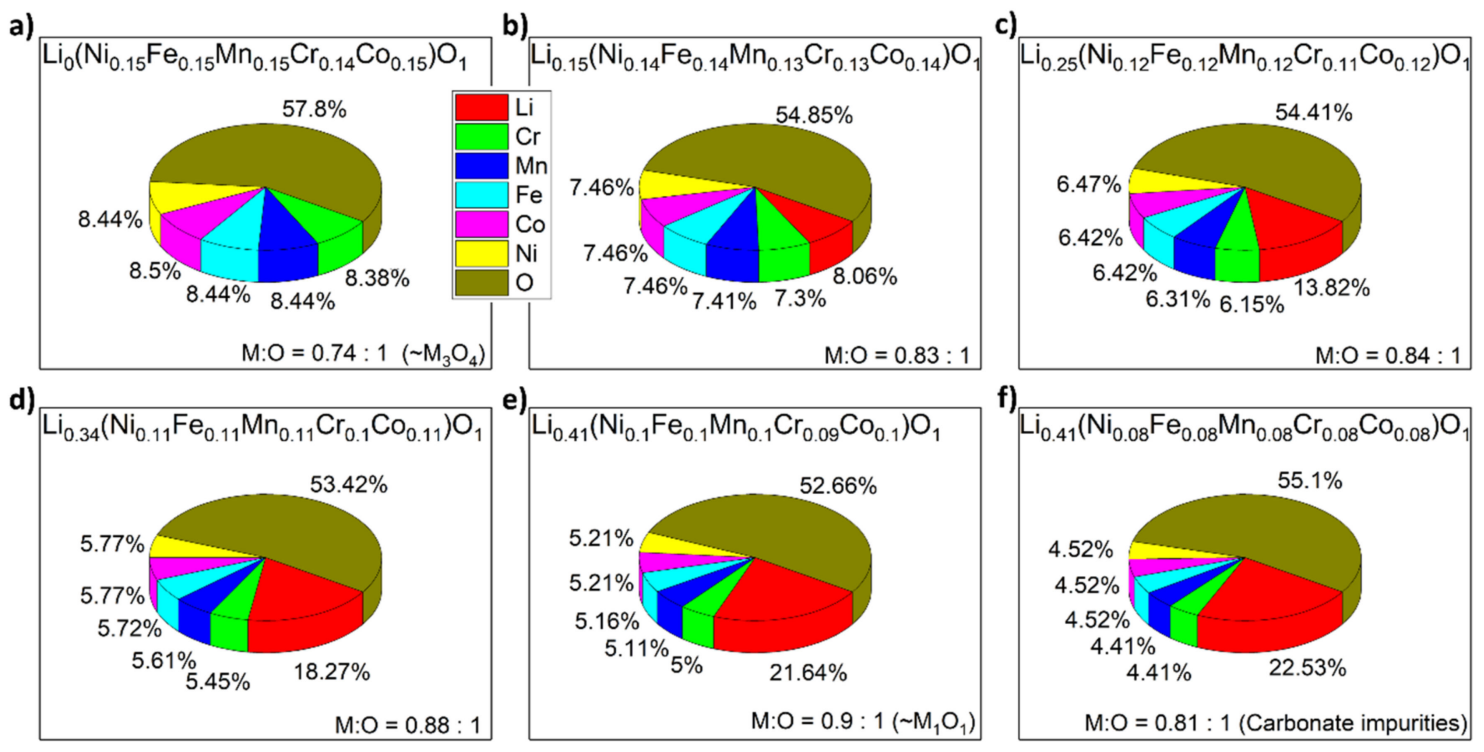

Figure 2. Inductively coupled plasma-optical emission spectroscopy (ICP-OES) of (a-f) HEO-1 with different Li contents. All numbers are given in units of at.\%. Increasing M:O ratio indicates transition from spinel to rock-salt phase. Excess oxygen is due to $\mathrm{Li}_{2} \mathrm{CO}_{3}$ formation. ICP-OES data for HEO-2 follow the same trend, but show the highest $\mathrm{M}: \mathrm{O}$ ratios for lower Li contents (Table 1). 
Table 1. Stoichiometries of HEO-1 and HEO-2 with different Li contents from ICP-OES analysis.

\begin{tabular}{|c|c|c|c|}
\hline & Normalized to $\mathrm{O}$ (Exact) & $\begin{array}{l}\text { Metal to Oxygen Ratio } \\
\text { (Exact) }\end{array}$ & $\begin{array}{l}\text { Normalized to Metals } \\
\text { Other than Li (Rounded) }\end{array}$ \\
\hline \multirow{6}{*}{ HEO-1 } & $\mathrm{Li}_{0}\left(\mathrm{Ni}_{0.15} \mathrm{Fe}_{0.15} \mathrm{Mn}_{0.15} \mathrm{Cr}_{0.14} \mathrm{Co}_{0.15}\right) \mathrm{O}_{1}$ & 0.74:1 $\left(\sim \mathrm{M}_{3} \mathrm{O}_{4}\right.$, spinel $)$ & $\mathrm{Li}_{0} \mathrm{M}_{1} \mathrm{O}_{1.4}$ \\
\hline & $\mathrm{Li}_{0.15}\left(\mathrm{Ni}_{0.14} \mathrm{Fe}_{0.14} \mathrm{Mn}_{0.13} \mathrm{Cr}_{0.13} \mathrm{Co}_{0.14}\right) \mathrm{O}_{1}$ & $0.83: 1$ & $\mathrm{Li}_{0.2} \mathrm{M}_{1} \mathrm{O}_{1.5}$ \\
\hline & $\mathrm{Li}_{0.25}\left(\mathrm{Ni}_{0.12} \mathrm{Fe}_{0.12} \mathrm{Mn}_{0.12} \mathrm{Cr}_{0.11} \mathrm{Co}_{0.12}\right) \mathrm{O}_{1}$ & $0.84: 1$ & $\mathrm{Li}_{0.4} \mathrm{M}_{1} \mathrm{O}_{1.7}$ \\
\hline & $\mathrm{Li}_{0.34}\left(\mathrm{Ni}_{0.11} \mathrm{Fe}_{0.11} \mathrm{Mn}_{0.11} \mathrm{Cr}_{0.10} \mathrm{Co}_{0.11}\right) \mathrm{O}_{1}$ & $0.88: 1$ & $\mathrm{Li}_{0.6} \mathrm{M}_{1} \mathrm{O}_{1.9}$ \\
\hline & $\mathrm{Li}_{0.41}\left(\mathrm{Ni}_{0.10} \mathrm{Fe}_{0.10} \mathrm{Mn}_{0.10} \mathrm{Cr}_{0.09} \mathrm{Co}_{0.10}\right) \mathrm{O}_{1}$ & 0.90:1 ( $\mathrm{M}_{1} \mathrm{O}_{1}$, rock-salt $)$ & $\mathrm{Li}_{0.8} \mathrm{M}_{1} \mathrm{O}_{2}$ \\
\hline & $\mathrm{Li}_{0.41}\left(\mathrm{Ni}_{0.08} \mathrm{Fe}_{0.08} \mathrm{Mn}_{0.08} \mathrm{Cr}_{0.08} \mathrm{Co}_{0.08}\right) \mathrm{O}_{1}$ & 0.81:1 (carbonate impurities) & $\mathrm{Li}_{1} \mathrm{M}_{1} \mathrm{O}_{2.5}$ \\
\hline \multirow{6}{*}{ HEO-2 } & $\mathrm{Li}_{0}\left(\mathrm{Ni}_{0.14} \mathrm{Fe}_{0.14} \mathrm{Mn}_{0.14} \mathrm{Cr}_{0.14} \mathrm{Mg}_{0.14}\right) \mathrm{O}_{1}$ & 0.70:1 $\left(\sim \mathrm{M}_{3} \mathrm{O}_{4}\right.$, spinel $)$ & $\mathrm{Li}_{0} \mathrm{M}_{1} \mathrm{O}_{1.4}$ \\
\hline & $\mathrm{Li}_{0.15}\left(\mathrm{Ni}_{0.14} \mathrm{Fe}_{0.13} \mathrm{Mn}_{0.13} \mathrm{Cr}_{0.13} \mathrm{Mg}_{0.14}\right) \mathrm{O}_{1}$ & $0.82: 1$ & $\mathrm{Li}_{0.2} \mathrm{M}_{1} \mathrm{O}_{1.5}$ \\
\hline & $\mathrm{Li}_{0.25}\left(\mathrm{Ni}_{0.12} \mathrm{Fe}_{0.12} \mathrm{Mn}_{0.12} \mathrm{Cr}_{0.12} \mathrm{Mg}_{0.12}\right) \mathrm{O}_{1}$ & $0.85: 1$ & $\mathrm{Li}_{0.4} \mathrm{M}_{1} \mathrm{O}_{1.7}$ \\
\hline & $\mathrm{Li}_{0.35}\left(\mathrm{Ni}_{0.11} \mathrm{Fe}_{0.11} \mathrm{Mn}_{0.11} \mathrm{Cr}_{0.11} \mathrm{Mg}_{0.11}\right) \mathrm{O}_{1}$ & $0.90: 1\left(\sim \mathrm{M}_{1} \mathrm{O}_{1}\right.$, rock-salt $)$ & $\mathrm{Li}_{0.6} \mathrm{M}_{1} \mathrm{O}_{1.8}$ \\
\hline & $\mathrm{Li}_{0.39}\left(\mathrm{Ni}_{0.10} \mathrm{Fe}_{0.10} \mathrm{Mn}_{0.10} \mathrm{Cr}_{0.10} \mathrm{Mg}_{0.10}\right) \mathrm{O}_{1}$ & $0.89: 1$ & $\mathrm{Li}_{0.8} \mathrm{M}_{1} \mathrm{O}_{2}$ \\
\hline & $\mathrm{Li}_{0.44}\left(\mathrm{Ni}_{0.08} \mathrm{Fe}_{0.08} \mathrm{Mn}_{0.08} \mathrm{Cr}_{0.08} \mathrm{Mg}_{0.08}\right) \mathrm{O}_{1}$ & 0.84:1 (carbonate impurities) & $\mathrm{Li}_{1.1} \mathrm{M}_{1} \mathrm{O}_{2.5}$ \\
\hline
\end{tabular}

XPS was conducted on both HEO-1 and HEO-2 (see Supplementary Information Figure S1 for HEO-3) to gain insights into the chemical states of the elements. Co in the non-lithiated HEO-1 was present as $\mathrm{Co}^{2+}\left(87 \%\right.$ of total $\mathrm{Co}$, from the characteristic $\mathrm{Co}^{2+}$ satellite peak at $\left.786.4 \mathrm{eV}\right)$. In contrast, for $\mathrm{Li}(\mathrm{NiFeMnCrCo}) \mathrm{O}(x=1)$, Co was in the oxidation state +3 (Figure 3a) [34-38]. As expected, $\mathrm{Mg}$ in the non-lithiated and lithiated HEO-2 (with Mg 1s binding energies of 1303.4 and $1303.7 \mathrm{eV}$, respectively) was present as $\mathrm{Mg}^{2+}$ (Figure 3b) [39,40]. Identification of the Ni oxidation state solely on the basis of the Ni 2p peak is challenging [34-38,41-44]. However, an overlay of all Ni $2 p$ spectra (Figure S1) of HEO-1 and HEO-2 revealed only minor differences among the lithiated and non-lithiated materials. Moreover, the spectra could be fitted with a multiplet set of $\mathrm{Ni}^{2+}$ ions according to the deconvolution approach presented in ref [35] (Figure 3c). Therefore, the oxidation state of Ni in the non-lithiated and lithiated HEO- 1 and HEO-2 can be assigned to +2 . $\mathrm{Cr}$ was present as $\mathrm{Cr}^{3+}$; however, the ions were partially oxidized to $\mathrm{Cr}^{6+}$ for the lithiated material. While $\mathrm{Cr}^{3+}$ showed multiplet splitting (Figure 3d), $\mathrm{Cr}^{6+}$ has an empty valence band and thus a sharp single peak at $579.9 \mathrm{eV}$ emerged (Figure 3d) $[38,45,46]$. According to the fitting results, in the lithiated HEO-1 and HEO-2 $(x=1), 50$ and $80 \%$ of total $\mathrm{Cr}$, respectively, were present as $\mathrm{Cr}^{6+}$. The increased $\mathrm{Cr}^{6+}$ fraction in HEO-2 is a direct result of the ceased $\mathrm{Co}^{2+/ 3+}$ redox couple.

Figure S1 reveals that the $\mathrm{Zn}$ ions in HEO-3 (with $\mathrm{Zn} 2 \mathrm{p}_{3 / 2}$ and $\mathrm{Zn}$ LMM binding energies of 1021.6 and $497.6 \mathrm{eV}$ [kinetic energy of $989 \mathrm{eV}$ ], respectively) are in the oxidation state +2 . The $\mathrm{Fe}$ 2 p spectra of HEO-1 in Figure 4a were not deconvoluted because of overlapping with the Co LMM Auger on the higher binding energy side of $\mathrm{Fe} 2 \mathrm{p}_{3 / 2}$. For HEO-2, peak fitting indicated the presence of $\mathrm{Fe}^{2+}(30 \%)$ and $\mathrm{Fe}^{3+}(70 \%)$ in the non-lithiated material and only $\mathrm{Fe}^{3+}$ in the lithiated material [38,47]. Because of intense multiplet splitting of $\mathrm{Mn}$ in the $2 \mathrm{p}$ data, usually the Mn $3 \mathrm{~s}$ and $3 p$ peaks are used to determine the oxidation state $[35,36,38,48]$. However, such analysis was hampered by the overlap of photoelectron peaks of $\mathrm{Mg}, \mathrm{Zn}, \mathrm{Li}, \mathrm{Fe}$, and Cr. Nevertheless, from the $\mathrm{Mn} 3 \mathrm{p}$ spectrum of the lithiated HEO-1 in Figure S1, the occurrence of peaks centered at 47.8 and $49.6 \mathrm{eV}$ was apparent. This in turn suggests the presence of at least two different Mn species [48]. Upon lithiation, the higher binding energy component emerged clearly, indicating $\mathrm{Mn}^{4+}$ contribution, whereas the lower binding energy peak in the Mn 3p spectrum suggests mixed $\mathrm{Mn}^{2+/ 3+}$ state (the binding energy is higher than that normally found for $\mathrm{Mn}^{2+}$ and lower than for $\mathrm{Mn}^{3+}$ ) [48]. The commonly observed multiplet splitting in Mn 2p $[35,36,38]$ and the overlap with the Ni LMM Auger line led to a large number of peaks in the fitting procedure. Following the fitting approach developed for battery cathode materials, as presented in refs $[35,36]$, the Mn 2p spectra for the non-lithiated HEO-1 and HEO-2 (Figure 4b) 
were fitted successfully assuming $\mathrm{Mn}^{3+}$ and $\mathrm{Mn}^{4+}$ multiplets. The fraction of $\mathrm{Mn}^{4+}$ in both of these materials was calculated to be $30 \%$. However, it increased to $90 \%$ for the lithiated HEO-1 and to $100 \%$ for the lithiated HEO-2 (the Mn $2 p$ peak could be fitted assuming only $\mathrm{Mn}^{4+}$ multiplets).

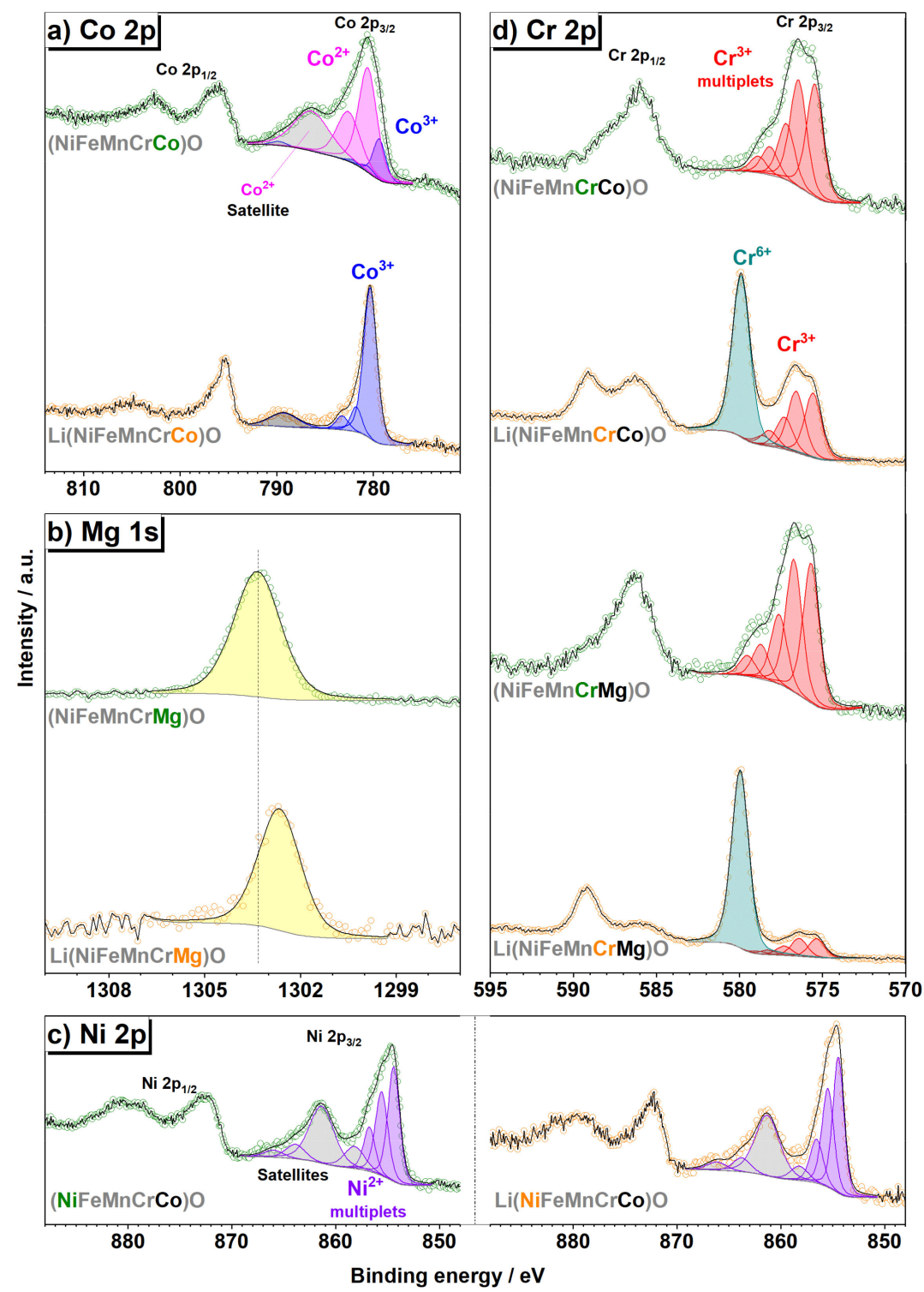

Figure 3. X-ray photoelectron spectroscopy (XPS) spectra of (a) Co for HEO-1, (b) Mg for HEO-2, (c) Ni for HEO-1, and (d) Cr for HEO-1 and HEO-2 in the non-lithiated $(x=0)$ and lithiated states $(x=1)$.

Moreover, inspection of the C 1s spectra of HEO-1 and HEO-2 (Figure S1) revealed a new, intense peak emerging at $290 \mathrm{eV}$ after lithiation. This peak coincided with an increase in intensity in the $\mathrm{O} 1 \mathrm{~s}$ spectrum at $531.5 \mathrm{eV}$ (Figure S1) and can be attributed to the formation of $\mathrm{Li}_{2} \mathrm{CO}_{3}$. This result agrees with previous related findings [35]. 


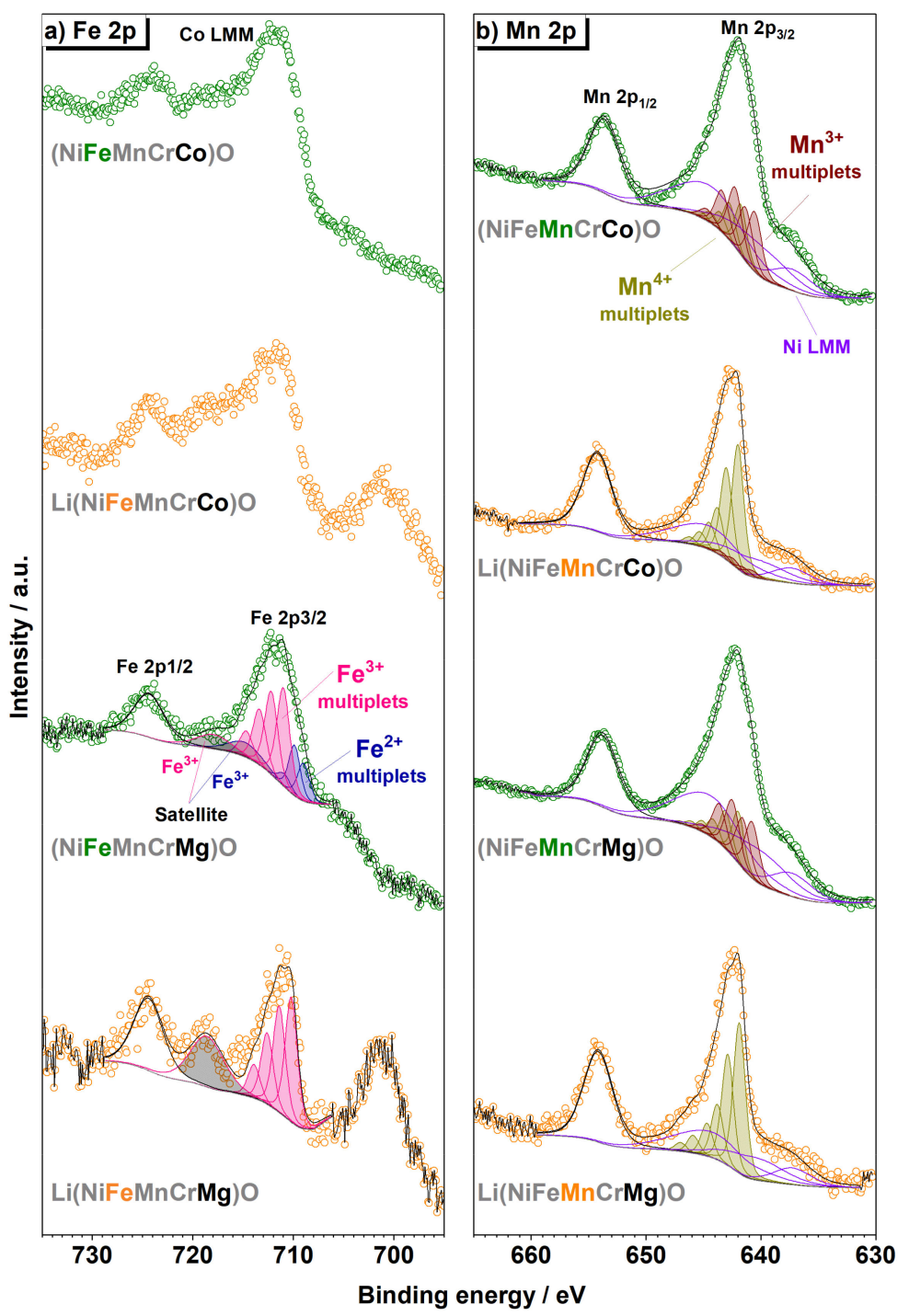

Figure 4. (a) Fe 2p and (b) Mn 2p XPS spectra of HEO-1 and HEO-2 in the non-lithiated $(x=0)$ and lithiated states $(x=1)$.

In summary, we conclude that the lithiation of HEO-1 and HEO-2 led to total or partial oxidation of $\mathrm{Co}, \mathrm{Mn}, \mathrm{Fe}$, and $\mathrm{Cr}$, whereas $\mathrm{Ni}, \mathrm{Zn}$ (in HEO-3), and $\mathrm{Mg}$ remained in their initial oxidation state (details in Table 2).

Table 2. Metal oxidation states and the corresponding fractions for HEO- 1 and HEO-2 in the non-lithiated $(x=0)$ and lithiated states $(x=1)$ from XPS analysis.

\begin{tabular}{|c|c|c|c|c|c|c|}
\hline & $\mathrm{Ni}$ & $\mathrm{Fe}$ & Mn & $\mathrm{Cr}$ & Co & Mg \\
\hline$(\mathrm{NiFeMnCrCo}) \mathrm{O}$ & $\mathrm{Ni}^{2+}$ & Not quantified & $\begin{array}{l}70 \% \mathrm{Mn}^{3+} \\
30 \% \mathrm{Mn}^{4+}\end{array}$ & $100 \% \mathrm{Cr}^{3+}$ & $\begin{array}{l}87 \% \mathrm{Co}^{2+} \\
13 \% \mathrm{Co}^{3+}\end{array}$ & - \\
\hline $\mathrm{Li}(\mathrm{NiFeMnCrCo}) \mathrm{O}$ & $\mathrm{Ni}^{2+}$ & Not quantified & $\begin{array}{l}10 \% \mathrm{Mn}^{3+} \\
90 \% \mathrm{Mn}^{4+}\end{array}$ & $\begin{array}{l}50 \% \mathrm{Cr}^{3+} \\
50 \% \mathrm{Cr}^{6+}\end{array}$ & $100 \% \mathrm{Co}^{3+}$ & - \\
\hline (NiFeMnCrMg)O & $\mathrm{Ni}^{2+}$ & $\begin{array}{l}30 \% \mathrm{Fe}^{2+} \\
70 \% \mathrm{Fe}^{3+}\end{array}$ & $\begin{array}{l}70 \% \mathrm{Mn}^{3+} \\
30 \% \mathrm{Mn}^{4+}\end{array}$ & $100 \% \mathrm{Cr}^{3+}$ & - & $\mathrm{Mg}^{2+}$ \\
\hline $\mathrm{Li}(\mathrm{NiFeMnCrMg}) \mathrm{O}$ & $\mathrm{Ni}^{2+}$ & $100 \% \mathrm{Fe}^{3+}$ & $100 \% \mathrm{Mn}^{4+}$ & $\begin{array}{l}20 \% \mathrm{Cr}^{3+} \\
80 \% \mathrm{Cr}^{6+}\end{array}$ & - & $\mathrm{Mg}^{2+}$ \\
\hline
\end{tabular}


Transmission electron microscopy (TEM) measurements were conducted to examine the materials' morphology and to probe the distribution of elements in the crystal structure. Note that non-uniform distribution would decrease the configurational entropy, thereby hinting at phase separation. Figure 5 shows high-resolution TEM micrographs of the non-lithiated and lithiated HEO-1 (see also high-angle annular dark-field scanning TEM [HAADF STEM] micrograph in Figure S2). In both cases, the particles, which consist of small crystallites, are of spherical shape, with sizes ranging from the nanometer to the micrometer length scale. Moreover, energy dispersive X-ray spectroscopy (EDX) in STEM mode of the same samples confirmed the uniform elemental distributions (Figure 6).

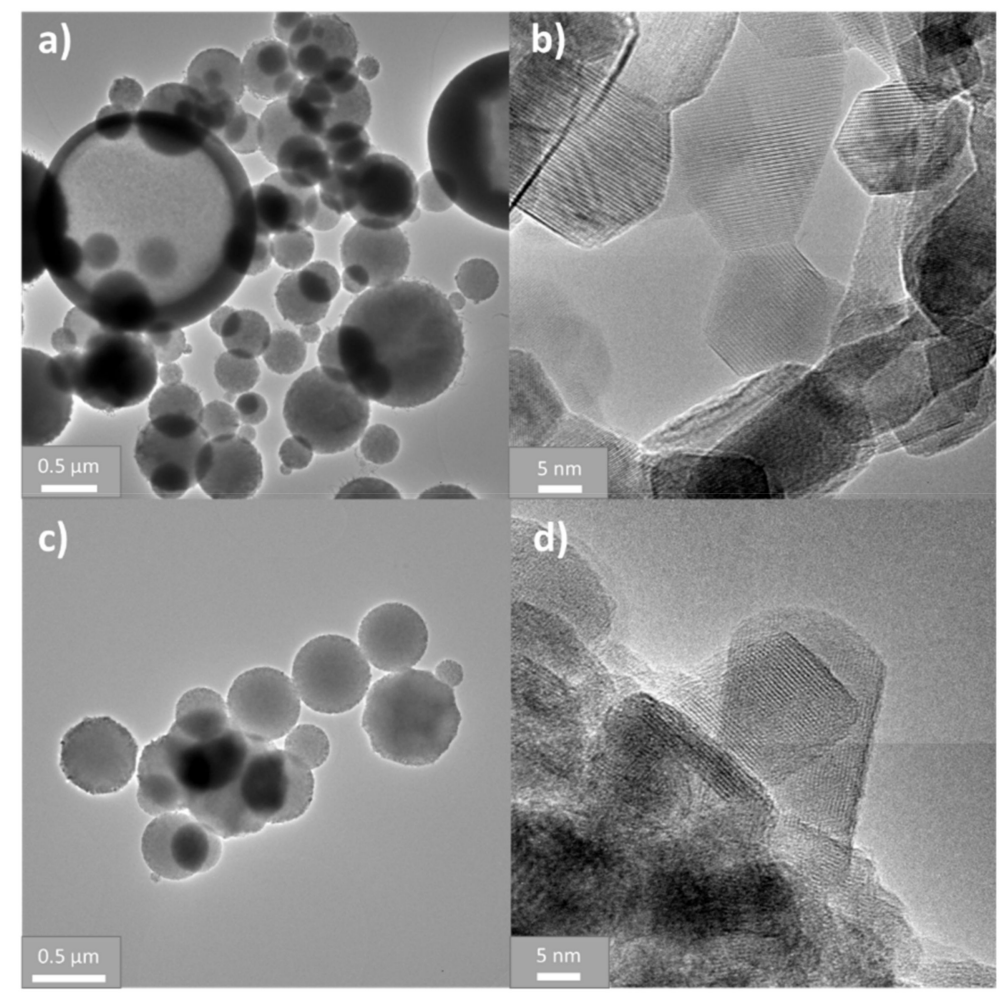

Figure 5. TEM micrographs at different magnifications of HEO-1 (a and $\mathbf{b})$ in the non-lithiated $(x=0)$ and (c and $\mathbf{d})$ lithiated states $(x=1)$.

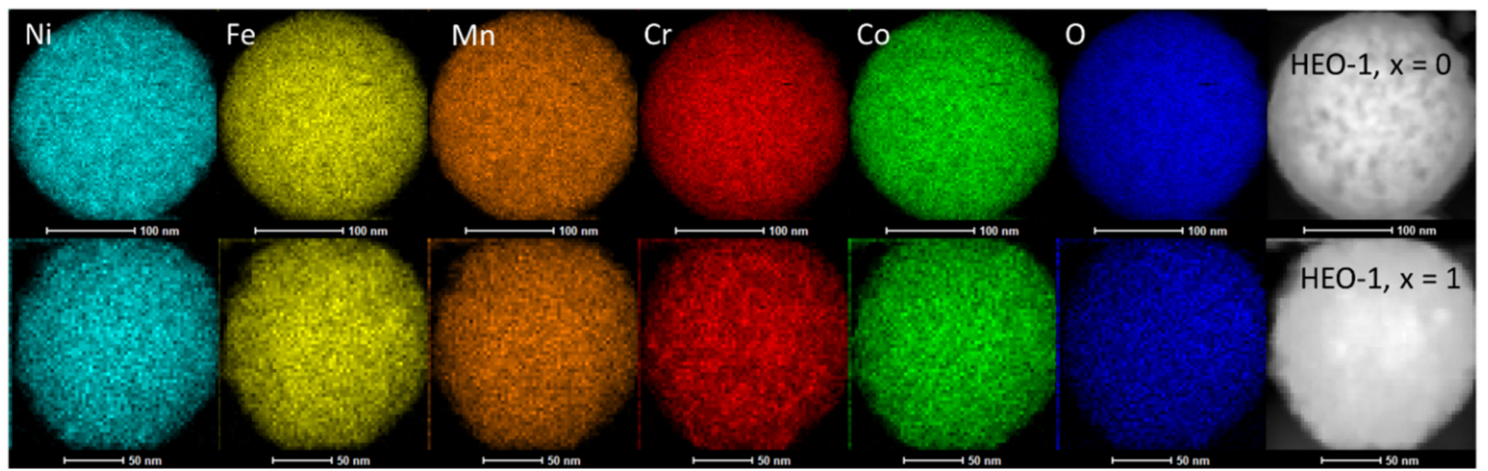

Figure 6. STEM-energy dispersive X-ray spectroscopy (EDX) mapping of HEO-1 in the non-lithiated $(x=0)$ and lithiated states $(x=1)$.

Attenuated total reflection infrared (ATR-IR) spectroscopy was performed to monitor the aforementioned carbonate formation. As can be seen from Figure 7, the lithiated HEO-1 and HEO-2 materials indeed produced characteristic carbonate bands $\left(1500 \mathrm{~cm}^{-1}, 1430 \mathrm{~cm}^{-1}, 870 \mathrm{~cm}^{-1}\right)$ [49]. Interestingly, an additional band appeared around $900 \mathrm{~cm}^{-1}$ after the phase transformation (for $x \geq 0.8$ ). 
This band can be assigned to $\mathrm{CrO}_{4}{ }^{2-}$, supporting the appearance of $\mathrm{Cr}^{6+}$ in the XPS spectra [50]. The fact that it was rather broad is probably because of the local environment with several different metal species present. At this time, it is unclear why $\mathrm{CrO}_{4}{ }^{2-}$ only formed after the structural transition. However, some explanation can be obtained from the experimental data. Both XPS and ATR-IR revealed the formation of surface contaminates (carbonate and chromate species) in the lithiated HEOs. Assuming that the rock-salt phase was saturated for $x=0.6-0.8$, a further increase in concentration would result in Li excess. Such Li-containing species may react with the ambient air and/or surrounding metal ions, thereby forming $\mathrm{Li}_{2} \mathrm{CrO}_{4}$ and $\mathrm{Li}_{2} \mathrm{CO}_{3}$. This was also corroborated by CGHE, indicating increasing oxygen contents for $x>0.8$ (HEO-1) and 0.6 (HEO-2).

a)

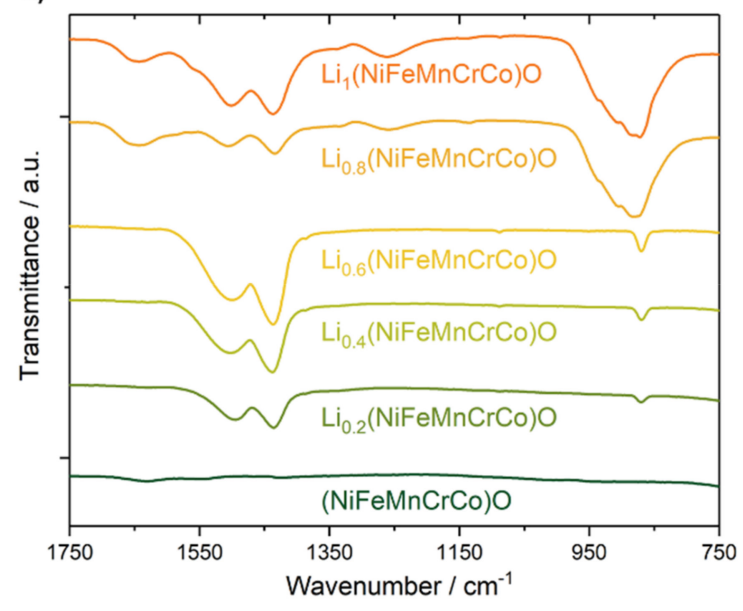

b)

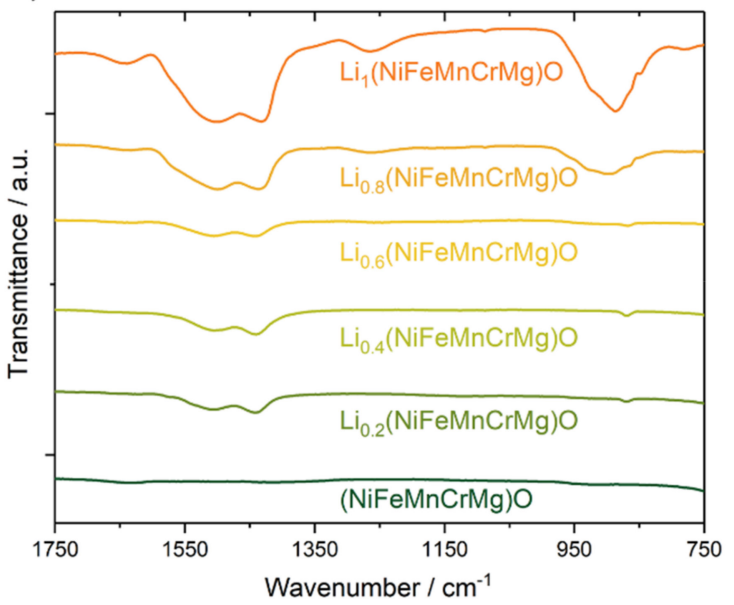

Figure 7. Attenuated total reflection infrared (ATR-IR) spectroscopy of (a) HEO-1 and (b) HEO-2 with different Li contents.

Finally, cyclic voltammetry was performed to learn about the redox behaviors of HEO-1 (Figure 8) and HEO-2 (Figure S3) as a function of Li content in the voltage ranges of 2.0-4.5 V and 0.1-3.0 V versus $\mathrm{Li}^{+} / \mathrm{Li}$. To this end, tape-cast electrodes were assembled in coin cells and cycled against Li metal as counter electrode. The sweep rate was set to $0.1 \mathrm{mV} / \mathrm{s}$. Figure $8 \mathrm{a}$ shows the cyclic voltammetric curves of the initial cycle for the low-voltage region. The reduction potential (cathodic peak position) was found to gradually increase with increasing $\mathrm{Li}$ concentration until the rock-salt phase was formed. This behavior differs from that of simple oxides. For example, rock-salt $\mathrm{CoO}$ and spinel $\mathrm{Co}_{3} \mathrm{O}_{4}$ have been shown to exhibit reduction potentials of 0.58 and $0.85 \mathrm{~V}$ versus $\mathrm{Li}^{+} / \mathrm{Li}$, respectively [51]. Overall, this result seems to be due to the increased oxidation state of metals in the rock-salt structure (high $\mathrm{Li}$ content), as shown in the section on XPS above. As can be seen from Figure 8a, the reduction potentials are $0.25 \mathrm{~V}$ for $x=0,0.37 \mathrm{~V}$ for $x=0.2,0.44 \mathrm{~V}$ for $x=0.4,0.52 \mathrm{~V}$ for $x=0.6,0.61 \mathrm{~V}$ for $x=0.8$, and $0.59 \mathrm{~V}$ for $x=1$. Except for the increase in $x$ from 0.8 to 1 , the reduction potential increased in a stepwise manner by $80-120 \mathrm{mV}$. Figure $8 \mathrm{~b}$ shows the cyclic voltammetric curves of the initial cycle for the high-voltage region. As somewhat expected, the spinel-type HEO-1 materials showed minor redox activity above $3.5 \mathrm{~V}$. However, for the highly lithiated, rock-salt structure HEO- 1 with $x \geq 0.8$, two pairs of oxidation/reduction peaks were observed. This result indicates that, after the transition to rock-salt phase, Li can be extracted from the lattice, leading to (partially) reversible redox behavior (see also cyclic voltammetric curves in Figure S4). However, whether or not this is directly connected to the structure or the Li concentration cannot be comprehensively concluded at this stage; further research is clearly required to answer this question. Nevertheless, the strong increase in specific current coincided with the structural changes detected by PXRD and ATR-IR. 
Lithiated HEO-1 $(x=1)$ was further studied to determine whether structural changes occur in the initial cycle. To this end, the electrodes were extracted from the cells after reaching $4.5 \mathrm{~V}, 2.0 \mathrm{~V}$, and after the first cycle (denoted by colored circles in Figure 9a) and probed using PXRD. As can be seen from Figure 9b, all patterns show the characteristic rock-salt reflections, thus indicating that the lattice structure is retained. However, some changes in reflection broadening are apparent and deserve more study.
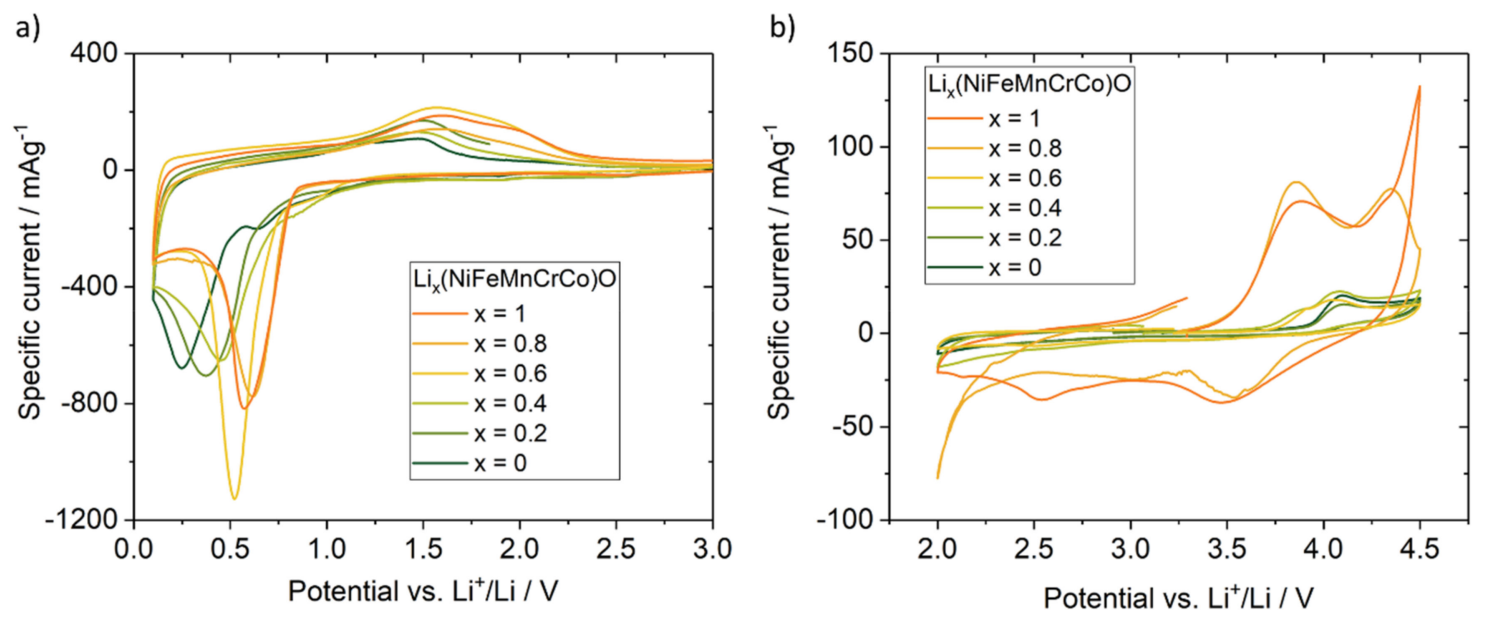

Figure 8. Cyclic voltammograms for HEO-1 with different Li contents in the voltage range of (a) $0.1-3.0 \mathrm{~V}$ and (b) 2.0-4.5 $\mathrm{V}$ versus $\mathrm{Li}^{+} / \mathrm{Li}$. Note that only the initial cycle is shown for clarity.

a)

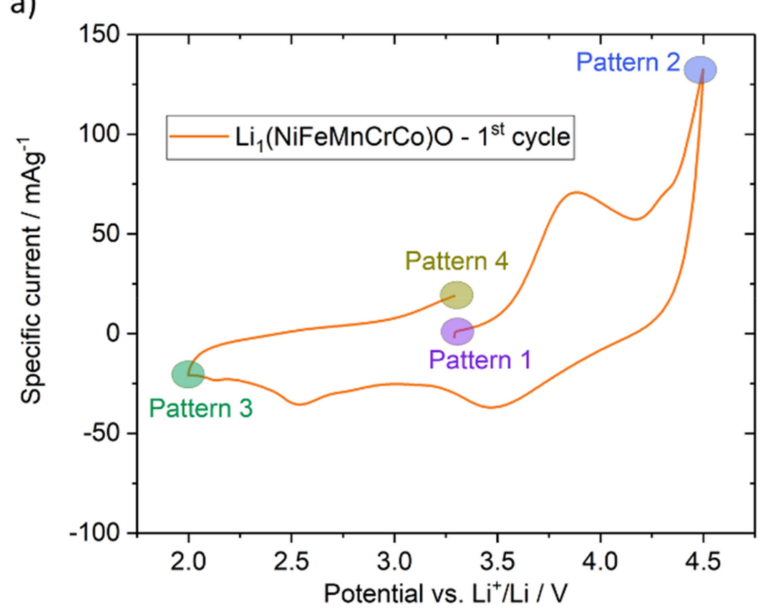

b)

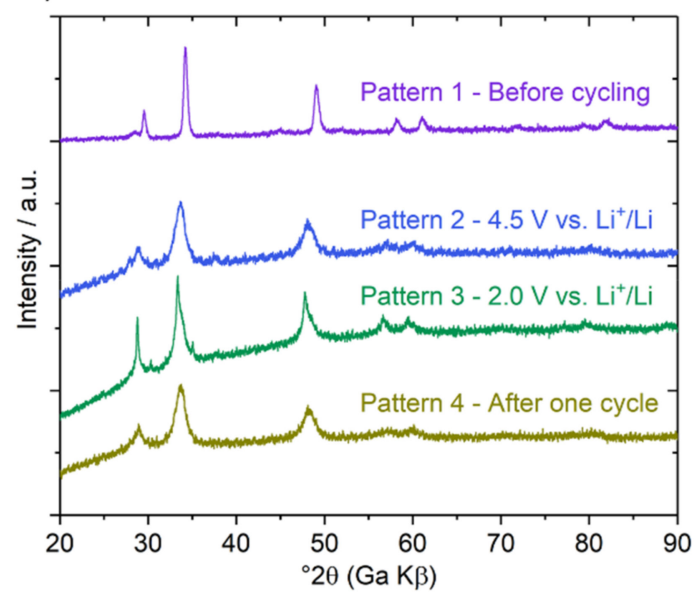

Figure 9. Structural changes during de/lithiation of HEO-1 (with $x=1$ ). (a) Representative cyclic voltammogram and $(\mathbf{b})$ the corresponding PXRD patterns.

\section{Conclusions}

In this work, three different HEOs were analyzed regarding the phase transformation from spinel to rock-salt with incorporation of monovalent $\mathrm{Li}^{+}$ions during synthesis. Charge compensation was found to be accompanied by full or partial oxidation of some of the elements (note that, interestingly, the $\mathrm{Ni}$ (II) did not change oxidation state during chemical lithiation). When oxidation was not possible, the spinel-type HEO transformed into a rock-salt phase of lower average charge. Hence, this transition can be tailored to some degree by replacing the multivalent elements (e.g., $\mathrm{Co}^{2+/ 3+} \rightarrow \mathrm{Mg}^{2+}$ and $\mathrm{Cr}^{3+/ 6+} \rightarrow \mathrm{Zn}^{2+}$ ) present in the lattice. Moreover, the formation of surface carbonate and chromate 
species in the rock-salt structure HEOs was observed via XPS and ATR-IR. Their formation seems to be associated with excess Li when exceeding a certain threshold concentration. Electrochemical testing using cyclic voltammetry revealed increasing redox activity with increasing Li content. In particular, the lithiated rock-salt HEOs deserve further investigation into their performance as negative and positive electrode materials in rechargeable lithium-ion batteries.

Supplementary Materials: The following are available online at http://www.mdpi.com/2673-3293/1/1/7/s1, Figure S1. XPS spectra of the O 1s, C 1s, Li 1s, Ni 2p, Zn 2p, Zn LMM, and Mg 1s core level regions for HEO-1 (with $x=0$ and 1), HEO-2 (with $x=0$ and 1), and HEO-3 (with $x=0.4$ ); Figure S2. HAADF STEM micrograph of HEO-1; Figure S3. Cyclic voltammograms of HEO-2 (with $x=0$ and 1) in the voltage range of a) $0.1-3.0 \mathrm{~V}$ and b) 2.0-4.5 V versus $\mathrm{Li}^{+} / \mathrm{Li}$. Note that only the initial cycle is shown; Figure S4. Cyclic voltammograms at $1 \mathrm{mV} / \mathrm{s}$ for the 5th to 12th cycles of HEO-1 (with $x=1$ ) in the voltage range of $2.0-4.5 \mathrm{~V}_{\text {versus }} \mathrm{Li}^{+} / \mathrm{Li}$.

Author Contributions: J.W. and D.S. conducted the synthesis and performed the electrochemical characterization. S.N. helped in the electrochemical testing and co-wrote the manuscript. K.W. performed the TEM measurements. J.J. and P.A.S. performed the ATR-IR spectroscopy measurements. J.M. and R.A. performed the XPS measurements, analyzed the data, and provided input to the manuscript. T.B. (Thomas Bergfeldt) was responsible for ICP-OES. A.S. and Q.W. planned and guided the experiments. M.B. contributed to the data discussion and proof reading. H.H., T.B. (Torsten Brezesinski), and B.B. supervised the work and co-wrote the manuscript. B.B. also performed the PXRD measurements. All authors have read and agreed to the published version of the manuscript.

Funding: A.S. and H.H. acknowledge financial support from the Helmholtz Association and the Deutsche Forschungsgemeinschaft (HA 1344/43-1). D.S., B.B., and Q.W. appreciate the support through EnABLES, a project funded by the Europeans Union's Horizon 2020 research and innovation program under grant agreement no. 730957. P.A.S. acknowledges the Ministry of Science, Research and Arts of the State of Baden-Wuerttemberg for funding research through the MERAGEM graduate school fellowship. J.J. acknowledges the German Academic Exchange Service (DAAD, no. 91650506). J.W. acknowledges financial support from the China Scholarship Council (CSC). S.N. acknowledges the Christian Bürkert Foundation.

Acknowledgments: The authors acknowledge the support from the Karlsruhe Nano Micro Facility (KNMF, www.knmf.kit.edu), a Helmholtz research infrastructure at Karlsruhe Institute of Technology (KIT, www.kit.edu). This work contributes to the research performed at CELEST (Center for Electrochemical Energy Storage Ulm-Karlsruhe).

Conflicts of Interest: The authors declare no conflict of interest.

\section{References}

1. Cantor, B.; Chang, I.T.H.; Knight, P.; Vincent, A.J.B. Microstructural development in equiatomic multicomponent alloys. Mater. Sci. Eng. A 2004, 375, 213-218. [CrossRef]

2. Yeh, J.-W.; Chen, S.-K.; Lin, S.-J.; Gan, J.-Y.; Chin, T.-S.; Shun, T.-T.; Tsau, C.-H.; Chang, S.-Y. Nanostructured High-Entropy Alloys with Multiple Principal Elements: Novel Alloy Design Concepts and Outcomes. Adv. Eng. Mater. 2004, 6, 299-303. [CrossRef]

3. Miracle, D.B.; Senkov, O.N. A critical review of high entropy alloys and related concepts. Acta Mater. 2017, 122, 448-511. [CrossRef]

4. Berardan, D.; Meena, A.K.; Franger, S.; Herrero, C.; Dragoe, N. Controlled Jahn-Teller distortion in (MgCoNiCuZn)O-based high entropy oxides. J. Alloys Compd. 2017, 704, 693-700. [CrossRef]

5. Sarkar, A.; Velasco, L.; Wang, D.; Wang, Q.; Talasila, G.; de Biasi, L.; Kübel, C.; Brezesinski, T.; Bhattacharya, S.S.; Hahn, H.; et al. High entropy oxides for reversible energy storage. Nat. Commun. 2018, 9, 3400. [CrossRef]

6. Sarkar, A.; Djenadic, R.; Usharani, N.J.; Sanghvi, K.P.; Chakravadhanula, V.S.K.; Gandhi, A.S.; Hahn, H.; Bhattacharya, S.S. Nanocrystalline multicomponent entropy stabilised transition metal oxides. J. Eur. Ceram. Soc. 2017, 37, 747-754. [CrossRef]

7. Rost, C.M.; Sachet, E.; Borman, T.; Moballegh, A.; Dickey, E.C.; Hou, D.; Jones, J.L.; Curtarolo, S.; Maria, J.P. Entropy-stabilized oxides. Nat. Commun. 2015, 6, 8485. [CrossRef]

8. Castle, E.; Csanádi, T.; Grasso, S.; Dusza, J.; Reece, M. Processing and Properties of High-Entropy Ultra-High Temperature Carbides. Sci. Rep. 2018, 8, 8609. [CrossRef]

9. Zhou, J.; Zhang, J.; Zhang, F.; Niu, B.; Lei, L.; Wang, W. High-entropy carbide: A novel class of multicomponent ceramics. Ceram. Int. 2018, 44, 22014-22018. [CrossRef] 
10. Gild, J.; Zhang, Y.; Harrington, T.; Jiang, S.; Hu, T.; Quinn, M.C.; Mellor, W.M.; Zhou, N.; Vecchio, K.; Luo, J. High-Entropy Metal Diborides: A New Class of High-Entropy Materials and a New Type of Ultrahigh Temperature Ceramics. Sci. Rep. 2016, 6, 37946. [CrossRef]

11. Jin, T.; Sang, X.; Unocic, R.R.; Kinch, R.T.; Liu, X.; Hu, J.; Liu, H.; Dai, S. Mechanochemical-Assisted Synthesis of High-Entropy Metal Nitride via a Soft Urea Strategy. Adv. Mater. 2018, 30, 1707512. [CrossRef] [PubMed]

12. Gild, J.; Braun, J.; Kaufmann, K.; Marin, E.; Harrington, T.; Hopkins, P.; Vecchio, K.; Luo, J. A high-entropy silicide: $\left(\mathrm{Mo}_{0.2} \mathrm{Nb}_{0.2} \mathrm{Ta}_{0.2} \mathrm{Ti}_{0.2} \mathrm{~W}_{0.2}\right) \mathrm{Si}_{2}$. J. Mater. 2019, 5, 337-343. [CrossRef]

13. Wang, Q.; Sarkar, A.; Wang, D.; Velasco, L.; Azmi, R.; Bhattacharya, S.S.; Bergfeldt, T.; Düvel, A.; Heitjans, P.; Brezesinski, T.; et al. Multi-anionic and -cationic compounds: New high entropy materials for advanced Li-ion batteries. Energy Environ. Sci. 2019, 12, 2433-2442. [CrossRef]

14. Oses, C.; Toher, C.; Curtarolo, S. High-entropy ceramics. Nat. Rev. Mater. 2020, 1-15. [CrossRef]

15. Bérardan, D.; Franger, S.; Dragoe, D.; Meena, A.K.; Dragoe, N. Colossal dielectric constant in high entropy oxides. Phys. Status Solidi Rapid Res. Lett. 2016, 10, 328-333. [CrossRef]

16. Dabrowa, J.; Stygar, M.; Mikuła, A.; Knapik, A.; Mroczka, K.; Tejchman, W.; Danielewski, M.; Martin, M. Synthesis and microstructure of the $(\mathrm{Co}, \mathrm{Cr}, \mathrm{Fe}, \mathrm{Mn}, \mathrm{Ni})_{3} \mathrm{O}_{4}$ high entropy oxide characterized by spinel structure. Mater. Lett. 2018, 216, 32-36. [CrossRef]

17. Zhao, C.; Ding, F.; Lu, Y.; Chen, L.; Hu, Y.S. High-Entropy Layered Oxide Cathodes for Sodium-Ion Batteries. Angew. Chemie Int. Ed. 2020, 59, 264-269. [CrossRef]

18. Bérardan, D.; Franger, S.; Meena, A.K.; Dragoe, N. Room temperature lithium superionic conductivity in high entropy oxides. J. Mater. Chem. A 2016, 4, 9536-9541. [CrossRef]

19. Sarkar, A.; Wang, Q.; Schiele, A.; Chellali, M.R.; Bhattacharya, S.S.; Wang, D.; Brezesinski, T.; Hahn, H.; Velasco, L.; Breitung, B. High-Entropy Oxides: Fundamental Aspects and Electrochemical Properties. Adv. Mater. 2019, 31, 1806236. [CrossRef]

20. Wang, Q.; Sarkar, A.; Li, Z.; Lu, Y.; Velasco, L.; Bhattacharya, S.S.; Brezesinski, T.; Hahn, H.; Breitung, B. High entropy oxides as anode material for Li-ion battery applications: A practical approach. Electrochem. Commun. 2019, 100, 121-125. [CrossRef]

21. Qiu, N.; Chen, H.; Yang, Z.; Sun, S.; Wang, Y.; Cui, Y. A high entropy oxide $\left(\mathrm{Mg}_{0.2} \mathrm{Co}_{0.2} \mathrm{Ni}_{0.2} \mathrm{Cu}_{0.2} \mathrm{Zn}_{0.2} \mathrm{O}\right)$ with superior lithium storage performance. J. Alloys Compd. 2019, 777, 767-774. [CrossRef]

22. Breitung, B.; Wang, Q.; Schiele, A.; Tripković, Đ.; Sarkar, A.; Velasco, L.; Wang, D.; Bhattacharya, S.S.; Hahn, H.; Brezesinski, T. Gassing Behavior of High-Entropy Oxide Anode and Oxyfluoride Cathode Probed Using Differential Electrochemical Mass Spectrometry. Batter. Supercaps 2020. [CrossRef]

23. Bo, S.H.; Li, X.; Toumar, A.J.; Ceder, G. Layered-to-Rock-Salt Transformation in Desodiated $\mathrm{Na}_{\mathrm{x}} \mathrm{CrO}_{2}(\mathrm{x} 0.4)$. Chem. Mater. 2016, 28, 1419-1429. [CrossRef]

24. Mohanty, D.; Kalnaus, S.; Meisner, R.A.; Rhodes, K.J.; Li, J.; Payzant, E.A.; Wood, D.L.; Daniel, C. Structural transformation of a lithium-rich $\mathrm{Li}_{1.2} \mathrm{Co}_{0.1} \mathrm{Mn}_{0.55} \mathrm{Ni}_{0.15} \mathrm{O}_{2}$ cathode during high voltage cycling resolved by in situ X-ray diffraction. J. Power Sources 2013, 229, 239-248. [CrossRef]

25. Thackeray, M.M.; Baker, S.D.; Adendorff, K.T.; Goodenough, J.B. Lithium insertion into $\mathrm{Co}_{3} \mathrm{O}_{4}$ : A preliminary investigation. Solid State Ionics 1985, 17, 175-181. [CrossRef]

26. Nam, K.M.; Shim, J.H.; Han, D.W.; Kwon, H.S.; Kang, Y.M.; Li, Y.; Song, H.; Seo, W.S.; Park, J.T. Syntheses and characterization of wurtzite $\mathrm{CoO}$, rocksalt $\mathrm{CoO}$, and spinel $\mathrm{Co}_{3} \mathrm{O}_{4}$ nanocrystals: Their interconversion and tuning of phase and morphology. Chem. Mater. 2010, 22, 4446-4454. [CrossRef]

27. Charlotte Li, J.; He, K.; Stach, E.A.; Su, D. Comparison of $\mathrm{Co}_{3} \mathrm{O}_{4}$ and $\mathrm{CoO}$ Nanoparticles as Anodes for Lithium-ion Batteries. Microsc. Microanal. 2015, 21, 477-478. [CrossRef]

28. Li, J.; He, K.; Meng, Q.; Li, X.; Zhu, Y.; Hwang, S.; Sun, K.; Gan, H.; Zhu, Y.; Mo, Y.; et al. Kinetic Phase Evolution of Spinel Cobalt Oxide during Lithiation. ACS Nano 2016, 10, 9577-9585. [CrossRef]

29. Parry, K.L.; Shard, A.G.; Short, R.D.; White, R.G.; Whittle, J.D.; Wright, A. ARXPS characterisation of plasma polymerised surface chemical gradients. Surf. Interface Anal. 2006, 38, 1497-1504. [CrossRef]

30. Scofield, J.H. Hartree-Slater subshell photoionization cross-sections at 1254 and 1487 eV. J. Electron Spectrosc. Relat. Phenomena 1976, 8, 129-137. [CrossRef] 
31. Tanuma, S.; Powell, C.J.; Penn, D.R. Calculations of electron inelastic mean free paths. IX. Data for 41 elemental solids over the $50 \mathrm{eV}$ to $30 \mathrm{keV}$ range. Surf. Interface Anal. 2011, 43, 689-713. [CrossRef]

32. Jung, R.; Morasch, R.; Karayaylali, P.; Phillips, K.; Maglia, F.; Stinner, C.; Shao-Horn, Y.; Gasteiger, H.A. Effect of Ambient Storage on the Degradation of Ni-Rich Positive Electrode Materials (NMC811) for Li-Ion Batteries. J. Electrochem. Soc. 2018, 165, A132-A141. [CrossRef]

33. Hatsukade, T.; Schiele, A.; Hartmann, P.; Brezesinski, T.; Janek, J. Origin of Carbon Dioxide Evolved during Cycling of Nickel-Rich Layered NCM Cathodes. ACS Appl. Mater. Interfaces 2018, 10, 38892-38899. [CrossRef] [PubMed]

34. Mariappan, C.R.; Kumar, V.; Azmi, R.; Esmezjan, L.; Indris, S.; Bruns, M.; Ehrenberg, H. High electrochemical performance of $3 \mathrm{D}$ highly porous $\mathrm{Zn}_{0.2} \mathrm{Ni}_{0.8} \mathrm{Co}_{2} \mathrm{O}_{4}$ microspheres as an electrode material for electrochemical energy storage. CrystEngComm 2018, 20, 2159-2168. [CrossRef]

35. Azmi, R.; Masoumi, M.; Ehrenberg, H.; Trouillet, V.; Bruns, M. Surface analytical characterization of $\mathrm{LiNi}_{0.8-\mathrm{y}} \mathrm{Mn}_{\mathrm{y}} \mathrm{Co}_{0.2} \mathrm{O}_{2}(0 \leq \mathrm{y} \leq 0.4)$ compounds for lithium-ion battery electrodes. Surf. Interface Anal. 2018, 50, 1132-1137. [CrossRef]

36. Azmi, R.; Trouillet, V.; Strafela, M.; Ulrich, S.; Ehrenberg, H.; Bruns, M. Surface analytical approaches to reliably characterize lithium ion battery electrodes. Surf. Interface Anal. 2018, 50, 43-51. [CrossRef]

37. Kumar, V.; Mariappan, C.R.; Azmi, R.; Moock, D.; Indris, S.; Bruns, M.; Ehrenberg, H.; Vijaya Prakash, G. Pseudocapacitance of Mesoporous Spinel-Type $\mathrm{MCo}_{2} \mathrm{O}_{4}(\mathrm{M}=\mathrm{Co}, \mathrm{Zn}$, and Ni) Rods Fabricated by a Facile Solvothermal Route. ACS Omega 2017, 2, 6003-6013. [CrossRef]

38. Biesinger, M.C.; Payne, B.P.; Grosvenor, A.P.; Lau, L.W.M.; Gerson, A.R.; Smart, R.S.C. Resolving surface chemical states in XPS analysis of first row transition metals, oxides and hydroxides: $\mathrm{Cr}, \mathrm{Mn}, \mathrm{Fe}, \mathrm{Co}$ and $\mathrm{Ni}$. Appl. Surf. Sci. 2011, 257, 2717-2730. [CrossRef]

39. Diler, E.; Lescop, B.; Rioual, S.; Nguyen Vien, G.; Thierry, D.; Rouvellou, B. Initial formation of corrosion products on pure zinc and $\mathrm{MgZn}_{2}$ examinated by XPS. Corros. Sci. 2014, 79, 83-88. [CrossRef]

40. Mittal, V.K.; Chandramohan, P.; Bera, S.; Srinivasan, M.P.; Velmurugan, S.; Narasimhan, S.V. Cation distribution in $\mathrm{Ni}_{\mathrm{x}} \mathrm{Mg}_{1-\mathrm{x}} \mathrm{Fe}_{2} \mathrm{O}_{4}$ studied by XPS and Mössbauer spectroscopy. Solid State Commun. 2006, 137, 6-10. [CrossRef]

41. Biesinger, M.C.; Payne, B.P.; Lau, L.W.M.; Gerson, A.; Smart, R.S.C. X-ray photoelectron spectroscopic chemical state quantification of mixed nickel metal, oxide and hydroxide systems. Surf. Interface Anal. 2009, 41, 324-332. [CrossRef]

42. Grosvenor, A.P.; Biesinger, M.C.; Smart, R.S.C.; McIntyre, N.S. New interpretations of XPS spectra of nickel metal and oxides. Surf. Sci. 2006, 600, 1771-1779. [CrossRef]

43. Payne, B.P.; Biesinger, M.C.; McIntyre, N.S. Use of oxygen/nickel ratios in the XPS characterisation of oxide phases on nickel metal and nickel alloy surfaces. J. Electron Spectrosc. Relat. Phenomena 2012, 185, 159-166. [CrossRef]

44. Biesinger, M.C.; Lau, L.W.M.; Gerson, A.R.; Smart, R.S.C. The role of the Auger parameter in XPS studies of nickel metal, halides and oxides. Phys. Chem. Chem. Phys. 2012, 14, 2434-2442. [CrossRef]

45. Payne, B.P.; Biesinger, M.C.; McIntyre, N.S. X-ray photoelectron spectroscopy studies of reactions on chromium metal and chromium oxide surfaces. J. Electron Spectrosc. Relat. Phenomena 2011, 184, $29-37$. [CrossRef]

46. Biesinger, M.C.; Brown, C.; Mycroft, J.R.; Davidson, R.D.; McIntyre, N.S. X-ray photoelectron spectroscopy studies of chromium compounds. Surf. Interface Anal. 2004, 36, 1550-1563. [CrossRef]

47. Grosvenor, A.P.; Kobe, B.A.; Biesinger, M.C.; McIntyre, N.S. Investigation of multiplet splitting of Fe 2p XPS spectra and bonding in iron compounds. Surf. Interface Anal. 2004, 36, 1564-1574. [CrossRef]

48. Töpfer, J.; Feltz, A.; Gräf, D.; Hackl, B.; Raupach, L.; Weissbrodt, P. Cation Valencies and Distribution in the Spinels $\mathrm{NiMn}_{2} \mathrm{O}_{4}$ and $\mathrm{M}_{\mathrm{Z}} \mathrm{NiMn}_{2-\mathrm{z}} \mathrm{O}_{4}(\mathrm{M}=\mathrm{Li}, \mathrm{Cu})$ Studied by XPS. Phys. Status Solidi 1992, 134, 405-415. [CrossRef]

49. Pasierb, P.; Komornicki, S.; Rokita, M.; Rękas, M. Structural properties of $\mathrm{Li}_{2} \mathrm{CO}_{3}-\mathrm{BaCO}_{3}$ system derived from IR and Raman spectroscopy. J. Mol. Struct. 2001, 596, 151-156. [CrossRef] 
50. Johnston, C.P.; Chrysochoou, M. Investigation of chromate coordination on ferrihydrite by in situ ATR-FTIR spectroscopy and theoretical frequency calculations. Environ. Sci. Technol. 2012, 46, 5851-5858. [CrossRef]

51. Reddy, M.V.; Prithvi, G.; Loh, K.P.; Chowdari, B.V.R. Li storage and impedance spectroscopy studies on $\mathrm{Co}_{3} \mathrm{O}_{4}, \mathrm{CoO}$, and $\mathrm{CoN}$ for Li-ion batteries. ACS Appl. Mater. Interfaces 2014, 6, 680-690. [CrossRef] [PubMed]

(C) 2020 by the authors. Licensee MDPI, Basel, Switzerland. This article is an open access article distributed under the terms and conditions of the Creative Commons Attribution (CC BY) license (http://creativecommons.org/licenses/by/4.0/). 